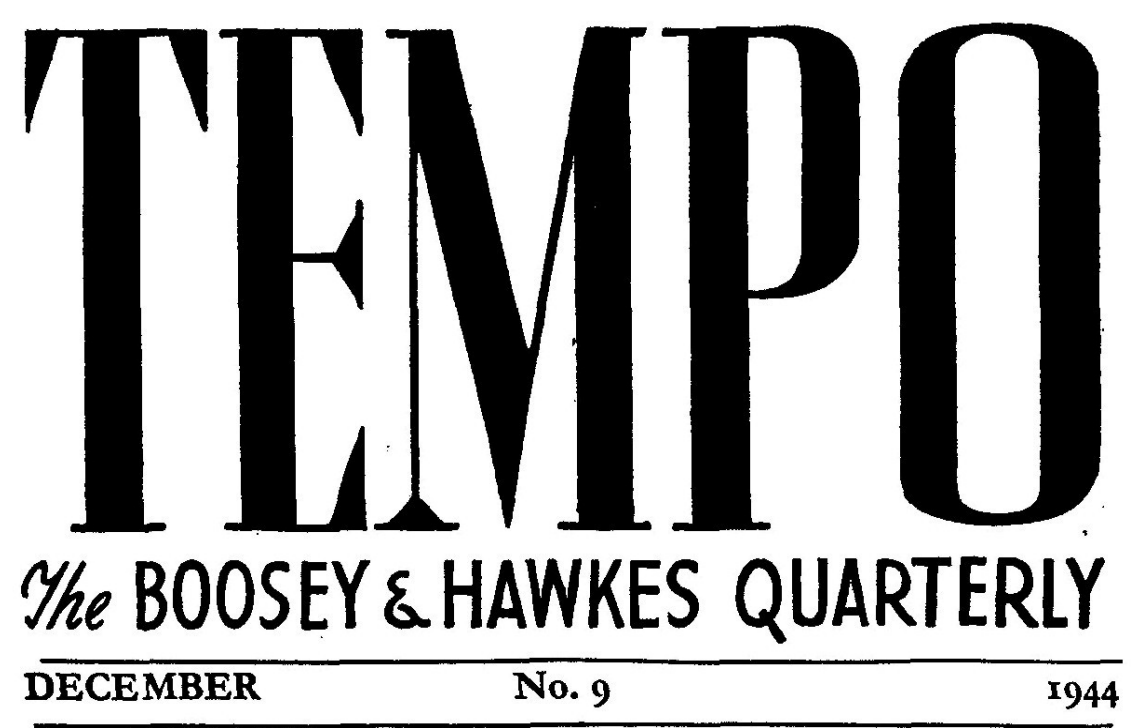

$$
\text { CONTENTS }
$$

Schoenberg in the $U_{\text {nited }} S_{\text {tates }}$

Aspects of Film Music

\title{
School Songs
}

The Plot of 'Peter Grimes'

Walton's 'Henry V' Music

Arthur Bliss's New Ballet

Bartók Portraits and Manuscript

The News from Paris, Brussels

$$
\text { and South Africa }
$$

etc.

Price One Shilling (net)
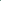
"For a long time 1 bave tried to find a modern concerto which I could thoroughly believe in, and in the Bartók I know I have discovered that work"

\section{BARTOK VIOLIN CONCERTO}

The first British performance of the Concerto was broadcast by Yehudi Menuhin and the B.B.C. Symphony Orchestra under Sir Adrian Boult, in the presence of a distinguished invited audience, at Bedford on September 2oth. The performance aroused the highest interest and lengthy Press comment, and the concerto was acclaimed as one of the outstanding works of our time. Mr. Menuhin, after giving concerts in France, returned specially to this country for a repeat performance on October 8th.

Composed six years ago, the concerto was first given in Amsterdam on April 23rd, I939 by the Hungarian violinist Zoltan Székely, with Willem Mengelberg and the Concertgebouw Orchestra. The American première took place at Cleveland in 1943, the soloist, Tossy Spivakovsky, subsequently playing it with the Pittsburgh Orchestra and (on three occasions) with the New York Philharmonic. Yehudi Menuhin made his first appearance in the concerto at Minneapolis (under Mitropoulous) last November, giving further performances in Washington and Baltimore.

\section{British Press Comments}

"It is extraordinarily impressive music, not at all forbidding even at first hearing, and leaves one more than ever certain that Bartók is one of the most alert creative minds now at work in Western music"-Scott Goddard (News Chronicle). "... it is the product of an original and powerful mind, and . . . it vindicates its own original and powerful premises "(The Times). "The composer's personal premises being granted and his well-known idiom accepted, the musical thinking is perfectly lucid and organic from first to last, and the craftsmanship is a joy ; . . . even at its most purely intellectual it commands not merely respect but admiration from first to last"-Ernest Newman (Sunday Times). " . . a a work comparable in weight and value with the great violin concertos of the last century. I say comparable : not necessarily equal-though it may well be"-Gerald Abraham (Music Review). "... now and then the composer breaks out into coloured orchestral effects that are rather pretty, or quite lovely, and full of music that anybody would call musical "W. McNaught (The Listener). "One of the most important musical events since the beginning of the war"-Ralph Hill (Radio Times).

Reduction for Violin and Piano, I2s. 6d.; Full Score and Miniature Score in the press; Orchestral Material on hire. Duration 32 minutes.

BOOSEY \& HAWKES, LTD. 


\section{TEMPO}

\section{THE BOOSEY \& HAWKES QUARTERLY}

\begin{tabular}{llr}
\hline DECEMBER & No. 9 & I944 \\
\hline
\end{tabular}

\section{O N T E N T S}

Schoenberg in the United States. Roger Sessions

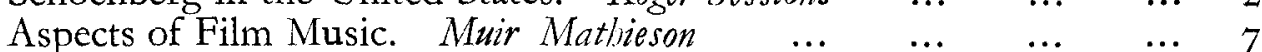

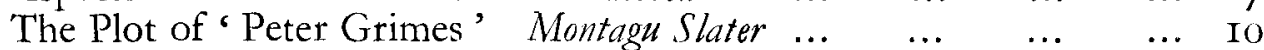

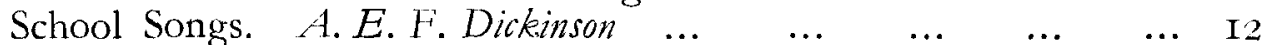

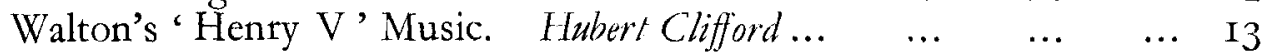

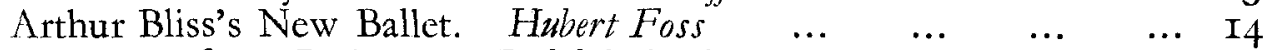

$\begin{array}{lllllll}\text { The News from Paris. I. Rudolph Dunbar } & \ldots & \ldots & \ldots & \ldots & \text { I5 }\end{array}$

II. Felix Aprabamian ... $\quad \ldots \quad \ldots . \quad \ldots \quad \ldots$ I6

$\begin{array}{llllllll}\text { Brussels carries on. Paul Tinel ... } & \ldots & \ldots & \ldots & \ldots & \ldots & \text { I8 }\end{array}$

$\begin{array}{lllllllll}\text { Music in the Making } & \ldots & \ldots & \ldots & \ldots & \ldots & \ldots & \ldots & \text { I9 }\end{array}$

$\begin{array}{lllllllll}\text { From South Africa } & \ldots & \ldots & \ldots & \ldots & \ldots & \ldots & \ldots & 2 \text { I }\end{array}$

$\begin{array}{llllllllll}\text { New Publications } & \ldots & \ldots & \ldots & \ldots & \ldots & \ldots & \ldots & 22\end{array}$

Supplements: Bartók Portraits and facsimile of manuscript

Four scenes from "Miracle in the Gorbals."

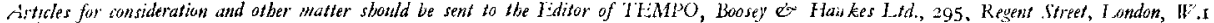

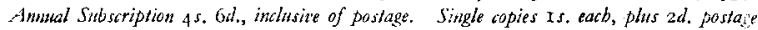
TLMPO is publisbed in March, Jane, September and December.

\section{CHAMBER MUSIC BY BENJAMIN BRITTEN \\ SUITE FOR VIOLIN AND PIANO, Op. 6}

A brilliantly written recital work, consisting of an Introduction, March, Moto Perpetuo, Lullaby and Waltz. It would act as an excellent foil to heavier works in a concert programme. Performed by Antonio Brosa and other violinis's. (5s.).

\section{PHANTASY QUARTET, Op. -2 \\ for Oboe, Violin, Viola and Violoncello.}

Recently revived in London by Eugene Goossens, to whom it is dedicated. "Everyone liked this fresh and pleasing work, which had a charming woodland and pastoral flavour"-Morning Post (on an early performance at Florence). Miniature Score, 3s. Set of Parts, 5s.

\section{STRING QUARTE'T No. I, Op. 25}

Performed by leading quartets in England, the Dominions and America. Forthcoming performances in Brussels, Palestine, Egypt. "It is a challenging work. Here, it says (as Debussy's Quartet said in I893), is a new way of writing for string quartet"-The Listener. "We may well be grateful for a work so enchanting to listen to"-The Spectator. (Miniature Score, 3s. 6d. Parts for hire, pending publication.)

Now Ready: A complete and detailed catalogue of Britten's published works, with a preface and a pencil portrait by Kenneth Green. (I 2 pages, $6 \mathrm{~d}$.).

BOOSEY \& HAWKES, LTD 